\title{
Frequency of pulp canal obliteration in primary teeth after traumatic dental injury and its association with related variables
}

\author{
Frequência de obliteração do canal pulpar nos dentes \\ decíduos após traumatismo dentário e sua \\ associação com variáveis relacionadas
}

\begin{abstract}
Samantha Alves do Nascimento MOURA ${ }^{1}$ iD https://orcid.org/0000-0001-5411-1265
Keilla Couto MACHADO ${ }^{1}$ iD https://orcid.org/0000-0001-6579-6781

Michele Machado LENZI ${ }^{1}$ iD https://orcid.org/0000-0002-6837-0564

Marcia Rejane Thomas Canabarro ANDRADE ${ }^{2}$ iD https://orcid.org/0000-0003-2165-7784

Mirian de Waele Souchois de MARSILLAC ${ }^{1}$ iD https://orcid.org/0000-0002-4452-7336
\end{abstract}

Vera CAMPOS1 ${ }^{1}$ iD https://orcid.org/0000-0002-5355-6999

\section{ABSTRACT}

Objective: The aim of this study was to determine the frequency of pulp canal obliteration (PCO) after traumatic dental injury (TDI) of primary anterior teeth and to investigate its relation with the related variables. Methods: This retrospective study has been done with dental records of patients selected from the Paediatric Dental Trauma Clinic between 2006 and 2016. Those who had PCO in the primary anterior teeth and were aged 0-108 months at the time of trauma were considered eligible. Data related to patients and TDI, such as sex, the child's age at the time of trauma, aetiology, affected teeth, the child's age at the time of the eruption of the permanent successor as well as the presence of crown discoloration were extracted from the dental records. Results: Among the 483 children with traumatised teeth, $14.9 \%$ had PCO and the most of them exhibited crown discoloration. The average age of the children at the time of the trauma was 38 months and the most common aetiology of the TDI was falls. The average time for the beginning of the PCO process was 13.5 months. There was no statistically significant association between the child's age at the time of trauma and the types of TDI, PCO and the presence of crown discoloration. Conclusion: The frequency of PCO was relatively low though the presence of crown discoloration was considerable. There was no association between the child's age at the time of trauma and the studied variable.

Indexing terms: Dental Pulp Cavity. Tooth Deciduous. Tooth Injuries.

\footnotetext{
$\checkmark v \nabla$

1 Universidade do Estado do Rio de Janeiro, Faculdade de Odontologia. Boulevard 28 de setembro, 157, sala 226, Rio de Janeiro, RJ, Brasil. Correspondence to: SAN MOURA. E-mail: <samantha.moura10@gmail.com>.

2 Universidade Federal Fluminense, Instituto de Saúde de Nova Friburgo. Rua Dr. Sílvio Henrique Braune, 22, Centro, Nova Friburgo, Rio de Janeiro, Brasil. Correspondence to: SMRTC ANDRADE. E-mail: <marciathomas13@gmail.com>.

$\boldsymbol{\nabla} \boldsymbol{\nabla}$

How to cite this article

Moura SAN, Machado KC, Lenzi MM, Andrade MRTC, Marsillac MWS, Campos V. Frequency of pulp canal obliteration in primary teeth after traumatic dental injury and its association with related variables. RGO, Rev Gaúch Odontol. 2021;69:e2021010. http://dx.doi. org/10.1590/1981-86372021001020190098
} 


\section{RESUMO}

Objetivo: O objetivo desse estudo foi determinar a frequência de obliteração do canal pulpar (OCP) após traumatismo dos dentes decíduos anteriores e investigar sua associação com variáveis relacionadas. Métodos: Este estudo retrospectivo foi realizado com base nos prontuários odontológicos de pacientes selecionados da Clínica de Trauma Dentário Pediátrico entre 2006 e 2016 . Aqueles que tinham OCP nos dentes decíduos anteriores e tinham entre 0-108 meses no momento do traumatismo foram considerados elegíveis. Dados dos pacientes e dos traumatismos, tais como, sexo, idade da criança no momento do traumatismo, etiologia, dente afetado, idade da criança na época no momento da erupção do sucessor permanente, bem como presença de alteração de cor da coroa foram extraídos dos prontuários. Resultados: Dentre as 483 crianças com dentes com traumatismos, 14.9\% tinham OCP e a maioria delas apresentava alteração de cor da coroa. A média de idade da criança no momento do traumatismo foi de 38 meses e a etiologia mais comumente associada ao TD foram as quedas. O tempo médio decorrido para o início do processo de OCP foi de 13,5 meses. Não houve associação estatisticamente significativa entre a idade da criança no momento do traumatismo e os tipos de TD, OCP e presença de alteração de cor da coroa. Conclusão: A frequência de OCP foi relativamente baixa, embora a presença de alteração da coroa tenha sido considerável. Não foi encontrada associação entre a idade da criança no momento do trauma e as variáveis estudadas.

Termos de indexação: Cavidade pulpar. Dente decíduo. Traumatismos dentários.

\section{INTRODUCTION}

Traumatic dental injuries (TDI) are very common in childhood and occur mostly between the ages of 1 and 4 years old [1-3]. The greatest number of traumas occur at home and falls from their own height are the most common causes of accidents [2,4-8]. Maxillary primary anterior teeth are usually involved with TDI and the incisors are the most affected $[5,9]$. The prevalence of trauma of the primary teeth in Brazilian children varies from 11 to $47 \%$ $[2,6,8,9,10]$. Primary teeth can have different sequelae due to TDI such as crown discoloration, pulp necrosis, pathological root resorption related to pulp inflammation, ankyloses or pulp canal obliteration [11-15].

Pulp canal obliteration (PCO) is a progressive tissue reaction of the dental pulp that can occur due to trauma in the primary teeth $[16,17]$. It is normally detected in radiographic exams as a not well-marked radiolucent image of the pulp chamber $[16,18]$. A tooth with this sequela presents a greyish crown becoming yellowish over time $[12,19]$. This is an important finding because the most parents or guardians seek a pediatric dentist due to this discoloration related to PCO, and its frequency it is not weel reported in the literature. Pulp canal obliteration can be classified as partial or total according to the radiographic image. In total pulp canal obliterations, the pulp chamber and the root canal are hardly visible (or not at all), while in partial obliterations, the pulp chamber is narrowed and the root canal is clearly visible $[13,14,20]$.

The aim of this study was to determine the frequency of pulp canal obliteration (PCO) after dental trauma of primary anterior teeth and to investigate its relation with the variables: presence of tooth crown discoloration and average time spent for the PCO to develop. This study also investigated whether age of TDI occurance, categorised into $<36$ months or $\geq 36$ months, had any association with the type of trauma, the type of obliteration and the presence of tooth crown discoloration.

\section{METHODS}

\section{Study design and study population}

This research is a retrospective study. Dental records from children that joined the Paediatric Dental Trauma Clinic at the Rio de Janeiro State University (FOUERJ) were selected from the list of patients who were treated between 2006 and 2016. Those who had some record of PCO in the primary anterior teeth (incisors and canines) and aged 0-108 months at the time of trauma were considered eligible for the study. Records that did not have signed consent were not included.

\section{Ethical considerations}

The study was approved by the Ethics Committee for research of the Pedro Ernesto University Hospital (Number of the approved protocol: 2683). The guardians/ parentes signed an informed consent form.

\section{Data collection}

All patients were examined by paediatric dentists previously trained by the same more experienced paediatric dentist. Clinical and radiographic exams were carried out 
at intervals of $7,15,30,90,180$ and 360 days according to the severity of the dental trauma. Data related to patients and TDI, such as sex, the child's age at the time of trauma, aetiology, types of affected teeth and trauma, the child's age at the time of the eruption of the permanent successor as well as the presence of crown discoloration were extracted from the dental records. It is relevant to note that one child could have more than one tooth affected by PCO. The collateral tooth was used as a parameter of comparison of the eruption date. All radiographs were evaluated by a single trained and experienced examiner in a darkened room using a negatoscope (NGP 91, Odonto Larcon), a black card mask and a magnifying glass lens (6X, Waltex-Lumagny). The radiographs were always analysed during the morning period and the limit of the examinations was $\leq 15$ films each session.

Pulp canal obliterations were diagnosed from radiographic exams in the dental records and classified as partial or total according to Jacobsen \& Sangnes [20]. Dental crown discoloration was detected visually by an experienced examiner as the presence of a yellowish hue [3]. As soon as any alteration was detected at recall visits, related to crown discoloration and/or radiographic PCO, it was recorded.

\section{Statistical analysis}

Data were processed using SPSS software version 17.0 (SPSS Inc., Chicago, III.,

USA). Descriptive analysis and association among the variables were performed. The Chisquare test was used to verify the association between the child's age at the time of trauma and the types of TDI, PCO and the presence of crown discoloration. The level of significance was set at 95\%.

\section{RESULTS}

Out of 1,230 children assisted in the Paediatric Dental Trauma Clinic, 734 children had some recorded data of TDI in the permanent dentition. Out of 496 children who had some record of TDI of the primary dentition in their data, 13 children were excluded because all the required information was not present in their dental records. Then, out of the 483 remaining children, 72 children (14.9\%) had a PCO recorded in their data and were included in this study, totalling 80 primary anterior teeth with this sequela.

Among the included children, 40 (55.6\%) were boys and $32(44.4 \%)$ were girls. The average age of the children at the time of the trauma was 38 months ( \pm 14.8 ), ranging from 10 to 70 months of age. The most common aetiology of the TDI was falls (88.8\%).

From the 80 teeth with obliteration, the right upper central incisor (55\%) and the left upper central incisor $(42.5 \%)$ were the most affected. The number of teeth with PCO per type of TDI is described in Table 1. Total pulp canal obliterations were diagnosed in 27 (33.8\%) teeth, while partial obliterations were diagnosed in 53 $(66.2 \%)$ teeth. The pulp canal obliterations occurred, on average, 13.5 months $( \pm 8.76)$ after the dental trauma.

Forty-nine $(61.3 \%)$ teeth were followed-up until the eruption of the permanent sucessor and the child's average age at the time of eruption was 81 months $( \pm 13)$. Forty-seven (58.8\%) teeth had obliteration and crown discoloration. Table 2 shows that there was no association between the child's age at the time of trauma and the types of TDI, PCO and the presence of crown discoloration.

Table 1. Number of teeth with pulp canal obliteration per type of traumatic dental injury.

\begin{tabular}{lcc}
\hline \multirow{2}{*}{ Type of TDI } & \multicolumn{2}{c}{ Teeth with PCO } \\
\cline { 2 - 3 } Enamel fracture & $\mathrm{n}$ & 13.8 \\
Crown fracture without pulp exposure & 11 & 2.5 \\
Concussion & 2 & 8.8 \\
Subluxation & 7 & 25 \\
Lateral luxation & 20 & 5 \\
Extrusive luxation & 4 & 6.2 \\
Intrusive luxation & 5 & 38.7 \\
\hline Total & 31 & 100 \\
\hline
\end{tabular}

Note: $\mathrm{n}$ : number of primary anterior teeth with PCO. 
Table 2. Association between the child age at the time of trauma and types of theDI, PCO, and the presence of crown discoloration.

\begin{tabular}{|c|c|c|c|c|c|c|}
\hline & & \multicolumn{4}{|c|}{ Age group } & \multirow{3}{*}{$p$ value* } \\
\hline & & \multicolumn{2}{|c|}{$<36$ months } & \multicolumn{2}{|c|}{$\geq 36$ months } & \\
\hline & & $\mathrm{n}$ & $(\%)$ & $\mathrm{n}$ & $(\%)$ & \\
\hline Type of TDI & Others & 26 & $(49.1)$ & 27 & $(50.9)$ & \\
\hline \multirow[t]{2}{*}{ Type of PCO } & Partial & 24 & $(45.3)$ & 29 & $(54.7)$ & 0.374 \\
\hline & Total & 14 & $(51.9)$ & 13 & $(48.1)$ & \\
\hline Crown discoloration & Absent & 15 & $(45.5)$ & 18 & (54.5) & \\
\hline
\end{tabular}

Note: *Chi-square test. TDI: traumatic dental injury. PCO: pulp canal obliteration. $n=80$ : number of primary anterior teeth with PCO.

\section{DISCUSSION}

This research is an important retrospective study of pulp canal obliteration (PCO) as a sequelae to the primary dentition since most parents and guardians seek pediatric dentists due to teeth's grayish or yellowish discoloration and dental literature does not reported clearly this finding. Pulp canal obliteration was present in $14.9 \%$ of the children who had some TDI in the primary dentition. Mello-Moura [13] reported a PCO prevalence of 20.2\% among children who suffered trauma in the upper primary incisors. Whereas, Santos [14] showed that 54\% of 112 traumatised primary maxillary central incisors exhibited PCO.

This study showed that boys and girls are affected equally by PCO in the primary dentition and this result is consistent with the literature $[13,14,20]$. The age of the children at the time of trauma ranged from 10 to 70 months and other studies observed that the children who had PCO were between 12-48 or 25-36 months old at the time of trauma $[20,21]$. According to Jacomo \& Campos [2], children between 1-4 years old have a high prevalence of dental trauma. The age of the child at the time of injury is an important factor for the occurrence of sequelae in the permanente successors [22].

The most frequent types of trauma in the primary anterior teeth with PCO were intrusive luxation and subluxation, which were also reported by other authors $[20,21]$. A study has showed that teeth which suffered luxation injuries were 1.35 times more likely to have PCO than teeth which suffered injury in the dental hard tissue [13]. However, according to transversal design of our study it was not possible to determine the relation between types of trauma in the primary anterior teeth and PCO.
As sequelae, partial pulp canal obliteration was observed more in our sample. This finding is in agreement with those observed by Jacobsen \& Sangnes [20]. Another study did not classify pulp canal obliterations the same as the present authors, but they observed that in $41 \%$ of all traumatised primary teeth, the degree of obliteration was less than $1 / 4$ of the pulp chamber [21]. The average time between the dental trauma and the development of PCO in this study was similar to others $[13,14,16]$, which reported the period to be within 12 months.

Few studies have studied PCO as a sequela of traumatised primary teeth or followed-up the primary teeth until the eruption of the permanent successors. The present study was able to do this and, like some studies, could observe that PCO does not affect the process of exfoliation as well as the eruption of the permanent successors $[3,20,23]$.

According to this study, the most of traumatised primary teeth with PCO had crown discoloration, this was also reported by other authors $[20,14]$. Similarly to this research, one study observed that there was no association between the child's age at the time of trauma and the presence of PCO, independent of the type [13]. Dental trauma and caries have a negative impact on the quality of life of preschool children [24]. Most parents notice dental crown discoloration due to dental trauma and ask questions about this condition, they are mostly concerned about the aesthetic implications [3]. It is important for paediatric dentists to consider responding to this request based on a correct diagnosis.

Although the prognosis of primary teeth with $\mathrm{PCO}$ is generally favourable [11], the management of such teeth includes periodical follow-up with clinical and radiographic exams until eruption of the permanent successors $[23,14]$. 
This follow-up can avoid future complications, such as delayed root resorption of the primary teeth and ectopic eruption of the permanent teeth successors [25].

\section{CONCLUSIONS}

This study showed a low frequency of pulp canal obliteration in traumatized primary anterior teeth and discoloration of their crowns. However, there was no association between the variables child's age at the time of trauma and the variables: types of TDI, PCO and the presence of crown discoloration.

\section{Collaborators}

We inform that SAN MOURA performed the experiments in partial fulfillment of requirements for a degree and wrote the manuscript. KC MACHADO wrote the manuscript. MM LENZI proofread the manuscript and consulted on and performed statistical evaluation. MRTC ANDRADE proofread the manuscript and consulted on and performed statistical evaluation. MWS MARSILLAC proofread the manuscript and contributed substantially to discussion. Campos $V$ participated in the project design, proofread the manuscript, contributed substantially to discussion.

\section{REFERENCES}

1. Carvalho V, Jacomo DR, Campos V. Frequency of intrusion in deciduous teeth and its effects. Dent Traumatol. 2010; 26(4): 304-7. http://dx.doi.org/10.1111/j.1600-9657.2010.00893.x

2. Jacomo DRES, Campos V. Prevalence of sequelae in the permanent anterior teeth after trauma in their predecessors: a longitudinal study of 8 years. Dent Traumatol. 2009;25(3):300-4. http://dx.doi.org/10.1111/j.1600-9657.2009.00764.x

3. Malmgren B, Andreasen JO, Flores MT, Robertson A, Di Angelis AJ, Andersson L, et al. International association of dental guidelines for the management of traumatic dental injuries: 3. Injuries in the primary dentition. Dent Traumatol. 2012;28(3):174-82. http://dx.doi.org/10.1111/j.1600-9657.2012.01146.x

4. Kramer PF, Zembruski C, Ferreira, SH, Feldens CA. Traumatic dental injuries in Brazilian preschool children. Dent Traumatol. 2003;19(6):299-303. http://dx.doi.org/10.1046/j.16009657.2003.00203.x

5. Lenzi MM, Jacomo DR, Carvalho V, Campos V. Avulsion of primary teeth and sequelaae on the permanent successors: longitudinal study. Braz J Dent Traumatol. 2011;2(2):80-4. http://dx.doi.org/10.1111/j.1600-9657.2005.00323.x

6. Scarpari CEO, Possobon RF, Moraes ABA. Ocorrência de traumatismos em dentes decíduos de crianças atendidas no CEPAE - FOP - UNICAMP. JBP Rev Ibero-Am Odontopediatr Odontol Bebê. 2004;35(7):33-40.
7. Tümem EC, Adiguzel O, Kaya S, Uysal E, Yavuz I, Atakul F. The prevalence and etiology of dental trauma among 5-72 months preschool children in South-Eastern Anatolia, Turkey. J Int Dent Med Res. 2009;2(2):40-4.

8. Wendt FP, Torriani DD, Assunção MCF, Romano AR, Bonow MLM, Costa CTC et al. Traumatic dental injuries in primary dentition: epidemiological study among preschool children in South Brazil. Dent Traumatol. 2010;26(2):168-73. http:// dx.doi.org/10.1111/j.1600-9657.2009.00852.x

9. Amorim LFG, Estrela C, Costa LRRS. Effects of traumatic dental injuries to primary teeth on permanent teeth: a clinical follow-up study. Dent Traumatol. 2011;27(2):117-21. http:// dx.doi.org/10.1111/j.1600-9657.2010.00959.x

10. Pugliese DMC, Cunha RF, Delbem ACB, Sundefeld MLMM. Influence of type of dental trauma on the pulp vitality and the time elapsed until treatment: a study in patients aged 0-3 years. Dent Traumatol. 2004;20(3):139-42. http://dx.doi. org/10.1111/j.1600-4469.2004.00242.x

11. Altun C, Cehreli ZC, Guven G, Acikel C. Traumatic intrusion of primary teeth and its effects on the permanent successors: a clinical follow-up study. Oral Surg Oral Med Oral Pathol Oral Radiol Endod. 2009;107(4):493-98. http://dx.doi.org/10.1016 /j.tripleo.2008.10.016

12. Holan G. Development of clinical and radiographic signs associated with dark discolored primary incisors following traumatic injuries: a prospective controlled study. Dent Traumatol. 2004;20(5): 276-87. http://dx.doi.org/10.1111/ j.1600-9657.2004.00285.x

13. Mello-Moura AC, Bonini GA, Zardetto CG, Rodrigues CR, Wanderley MT. Pulp calcification in traumatized primary teeth: prevalence and associated factors. J Clin Pediatr Dent. 2011;35(4):383-7. http://dx.doi.org/10.17796/ jcpd.35.4.8065636750168677

14. Santos BZ, Cardoso MC, Almeida ICS. Pulp canal obliteration following trauma to primary incisors: a 9-year clinical study. Pediatr Dent. 2011;33(5):399-402.

15. Tümen EC, Adigüzel O, Kaya S, Uysal E, Yavuz I, Özdemir $\mathrm{E}$, et al. Incisor trauma in a Turkish peeschool population: prevalence and sócio-economic risk factors. Communit Dent Health. 2011;28(4):308-12.

16. Borum MK, Andreasen JO. Sequelaae of trauma to primary maxillary incisors. I. Complications in the primary dentition. Endod Dent Traumatol. 1998;14(1):31-44. http://dx.doi. org/10.1111/j.1600-9657.1998.tb00806.x

17. Gondim JO, Moreira-Neto JJS. Evaluation of intruded primary incisors. Dent Traumatol. 2005;21(2):131-3. http://dx.doi. org/10.1111/j.1600-9657.2005.00288.x

18. Fried I, Erickson P, Schwartz S, Keenan K. Subluxation injuries of maxillary primary anterior teeth: epidemiology and prognosis of 207 traumatized teeth. Pediatr Dent. 1996;18(2):145-51.

19. Diab MD, Elbadrawy $H$. Intrusion injuries of primary incisors. Parte II: Sequelaae affecting the intruded primary incisors. Quintessence Int. 2000;31(5):335-41.

20. Jacobsen I, Sangnes G. Traumatized primary anterior teeth. Acta Odontol Scand. 1978;36(4):199-204. http://dx.doi. org/10.3109/00016357809004668 
21. Robertson A, Lundgren $T$, Andreasen JO, Dietz $W$, Hoyer I, Norén JG. Pulp calcifications in traumatized primary incisors: a morphological and inductive analysis study. Eur J Oral Sci. 1997;105(3): 196-206. http://dx.doi. org/10.1111/j.1600-0722.1997.tb00201.x

22. Lenzi MM, da Silva Fidalgo TK, Luiz RR, Maia LC. Trauma in primary teeth and its effect on the development of permanent successors: a controlled study. Acya Odontol Scand. 2019;77(1):76-81. http://dx.doi.org/10.1080/000163 57.2018 .1508741

23. Andreasen JO, Andreasen FM. Textbook and color atlas of traumatic injuries to the teeth. 3rd ed. Copenhagen: Mosby; 1994.
24. Firmino RT, Gomes MC, Clementino MA, Martins CC, Paiva SM, Granville-Garcia AF. Impact of oral health problems on the quality of life of preschool children: a case-control study. Int J Paediatr Dent. 2016;26(4):242-9. http://dx.doi.org/10.1111/ ipd.12182

25. Ravn JJ. Sequelae of acute mechanical traumata in the primary dentition. A clinical study. ASDC J Dent Child. 1968;35(4):281-9.

Received on: 10/6/2019

Final version resubmitted on: 7/10/2019

Approved on: 19/11/2019 